\title{
Pensononowoor
}

2014, vol. 71, 101-108

http://dx.doi.org/10.12657/denbio.071.010

\author{
Antonín Martinik, Lumír Dobrovolný, Eva Palátová
}

\section{Tree growing space and acorn production of Quercus robur}

Received: 01 March 2013; Accepted 04 July 2013

\begin{abstract}
Pedunculate oak (Quercus robur L.) is considered the main commercial tree species in conditions of floodplain forests of central Europe. In the Czech Republic clear-cutting silvicultural system represents a prevailing regeneration method of oak stands in floodplain forest. The natural regeneration is limited only in stands and years with sufficient acorn production. We analysed an acorn crop periodicity and an influence of canopy opening to the acorn production in South Moravian floodplain forest, Czech Republic between 2008 and 2011, The acorn crop from trees with different growth spaces in four stand conditions (closed canopy (A), moderate open canopy (B), open canopy (C) and single growing trees (D) with unlimited growth space was analysed. The amount of acorns was determined using seed traps placed under the crowns of sample trees. The average amount of acorns in 2009 and 2011 ranged from 13 (A) to 102 (C)/m² and from 2 (A) to $124(\mathrm{D}) / \mathrm{m}^{2}$, respectively. At the same time, a considerable difference was recorded in the fructification of sample trees in the various stand situations. Significant correlations were confirmed between the amount of acorns and crown size $\left(\mathrm{r}_{2009}^{2}=0.27, \mathrm{r}_{2011}^{2}=0.07\right)$ of parent trees and their growth space - release area $\left(r^{2}{ }_{2009}=0.42, r_{2011}^{2}=0.25\right)$ and social area $\left(r_{2009}^{2}=0.31, r_{2011}^{2}=0.26\right)$. The production of acorns could be affected by establishing conditions for the pedunculate oak with a minimum crown projection area in adult trees of at least $70 \mathrm{~m}^{2}$ and/or with a minimum release area of $300 \mathrm{~m}^{2}$, it means spacing between parent trees about $10 \mathrm{~m}$ or 100 trees per 1 ha.
\end{abstract}

Additional key words: floodplain forest, acorn production, acorn quality, crown release

Address: A. Martiník, L. Dobrovolný, E. Palátová, Department of Silviculture, Faculty of Forestry and Wood Technology, Mendel University in Brno, Brno 613 00, Czech Republic, e-mail: martinik@mendelu.cz

\section{Introduction}

Pedunculate oak (Quercus robur L.) represents the main commercial tree species of floodplain forests in the Czech Republic (Poleno and Vacek 2007). The predominant silvicultural system applied in these forests is large-scale clear-felling with the subsequent artificial oak regeneration. Even-aged, single-storey stands of pedunculate oak establish dense canopies with narrow crowns and minimal fructification.

The pedunculate oaks begin to fructify at the age of 40-50 in the open and at the age of 70-80 years in dense canopies (Palátová 2008; Vyskot 1958). In the open, they fructify nearly every year while in stands, seed years repeat every 4-8 years (Svoboda 1955). The reconstruction of the past seed years for 
pedunculate oak in the Czech Republic is unclear because the oak crop was recorded cumulatively for sessile and pedunculate oak together. While the sessile oak has shown abundant and regular crops in recent years, the fructification of pedunculate oak has been rare. In this sense, 1999 was particularly significant with the number of acorns in the South Moravian floodplain forests reaching $63 / \mathrm{m}^{2}$ (Vaňková 2004). Major acorn crops were also recorded in 2003 and 2006. According to Klimo et al. (2008) the fructification in Croatia appears periodically every 3 to 5 years or every 2 years (Gradečki-Poštenjak et al. 2011). Aussenac (1957 in Poleno and Vacek 2009) reports 8 full and 11 partial seed years in surroundings of Nancy, France over 106 years during 1865-1971 periods. Different and irregular fructification periodicity was also confirmed for other oak species both in Europe and in North America (Shaw 1968; Koenig et al. 1994; Bellocq et al. 2005).

Factors which conclusively affect fructification are site and stand conditions, crown size, tree position as well as climate history (Dey 1995; Klimo et al. 2008). Climatic factors influencing the fructification of oak include unfavourable temperature and precipitation conditions in the time of flowering and the occurrence of stress caused by drought or frost periods during previous years (Harapin et al. 1996; Koenig et al. 1996 and 2010; Askeyev et al. 2005). Several hypotheses and causes were generally discussed by Kelly (1994) and Koenig et al. (1994) when explaining the occurrence of strong mast years in oak stands. The most relevant ones include the synchronized flowering of the majority of trees in a given locality, the lower adaptation ability of trees to pests and also the abundance of nutrients and substances required for the development of seeds (Sork et al. 1993; Kelly 1994). Most authors mention a considerable variability of oak fructification between individuals, between stands or different localities and between individual years (Crawley and Long 1995; Chalupa 1973; Matić et al. 1996).

A complex of harmful biotic and abiotic factors resulting in oak decline has been recorded across Europe since the end of 1980s (Oosterbaan and Nabuurs 1991; Gaertig et al. 2002; Čater and Batič 2006). Apart from insect pests as secondary factors have technical regulations in the landscape (waterbed regulations) led to changed water regime changes in floodplains and altered the availability of the groundwater table especially in growing season, to which the pedunculate oak is particularly sensitive (Čater 2011; Levanič et al. 2011). One of eventual consequences of these changes and the physical weakening of oaks may be also reduced productivity (Klimo et al. 2008; Pernar et al. 2009). The decrease of oak vitality and increased dieback could also lead to decreased fertility.
A commonly used practical method to induce the acorn production of acorns is the crown release, which is used like silviculture treatment in older stands before regeneration (Vyskot 1958; Matić et al. 1999; Matić et al. 2003).

Seed-tree or shelterwood methods have been studied in North America for the northern red oak (Bellocq et al. 2005; Dey 1995; Dey et al. 2009). The positive influence of such tending focused on the release of oak crowns has been emphasized as the basic prerequisite for higher acorn productivity. Special attention should also be paid to the identification of individual trees which fructify at their middle age and to their promotion and release for the future (Dey 1995; Healy 1997).

The systematic management of the crowns of parent trees and the identification of fructifying individual trees appear to be the key silvicultural measure for increased acorn production.

The aim of our study was to evaluate if different growing space between pedunculate oaks affects the production of acorns on floodplain sites. We also studied acorn production in relation with different release rates.

\section{Materials and methods}

The surveys were conducted in forest stands with a dominant share of pedunculate oaks on Židlochovice floodplain sites, Czech republic $\left(49^{\circ} 0^{\prime} \mathrm{N}, 16^{\circ} 37^{\prime} \mathrm{E}\right)$ in altitudes ranging around 177 mamsl with the average air temperature $9^{\circ} \mathrm{C}$ and $550 \mathrm{~mm}$ annual precipitation. The predominating soil type, Cambic Fluvisol is slightly gleyic, eubasic in double substrates with chernozem fossils (ca. from $160 \mathrm{~cm}$ ) on fluvial, loamy up to loamy-sandy Holocene sediments. The experimental stands are situated on the northern margin of the area. Potential vegetation type is defined as elm-pedunculate oak woodlands (Querco-Ulmetum) (Neuhäuslová et al. 1998).

Fructification intensity was monitored in three forest stands under regeneration stage with different spatial structures - different area of growth spaces for (oak) trees. In each stand representing the given stand situation, a research plot was established out (RP), each with five adult, socially predominating sample trees. The size of the research plot depended on the spacing distance of samples trees which was in average 0.5 ha. Experiment included also solitary trees (standards) with highest surrounding area. Four different stand (crown) conditions were applied in the study; closed canopy conditions (A) with single-storey oak stand and dense canopy, representing the most common stand type of the study area, moderate openness of the canopies (B), structured stand with two distinctive storeys and moderately open up- 
Table 1. Basic research plot parameters

\begin{tabular}{cccccccccc}
\hline $\begin{array}{c}\text { Stand con- } \\
\text { ditions }\end{array}$ & $\mathrm{dbh}[\mathrm{cm}]$ & $\mathrm{h}[\mathrm{m}]$ & $\mathrm{h}_{\mathrm{cb}}[\mathrm{m}]$ & $\mathrm{A}_{\mathrm{c}}\left[\mathrm{m}^{2}\right]$ & $\mathrm{d}_{\mathrm{n}}[\mathrm{m}]$ & $\mathrm{V}\left[\mathrm{m}^{3} \mathrm{ha}^{-1}\right]$ & $\begin{array}{c}\mathrm{G}^{2} \mathrm{ha}^{-1} \\
{\left[\mathrm{~m}^{2} \mathrm{ha}^{-1}\right]}\end{array}$ & $\mathrm{sd}$ & $\mathrm{C}_{\mathrm{c}}[\%]$ \\
\hline A & 52.4 & 34.4 & 22.6 & 50.2 & 5.48 & 674.45 & 47.90 & 1.05 & 111 \\
B & 46.2 & 28.8 & 17.8 & 54.1 & 6.14 & 349.26 & 29.35 & 0.68 & 100 \\
C & 53.2 & 29.9 & 16.3 & 74.9 & 7.98 & 299.09 & 23.82 & 0.48 & 76 \\
\hline
\end{tabular}

A closed canopy, B slight openness, $\mathrm{C}$ wide openness, $\mathrm{D}$ remnants, dbh breast height diameter, $\mathrm{h}$ tree height, $\mathrm{h}$ height of the crown base, $A_{c}$ projected crown area, $d_{n}$ average distance to the nearest neighbour, $V$ total volume, $G$ total basal area, sd (V/Vtable) stock density, Cc $(\Sigma \mathrm{P} /$ area of $\mathrm{RP})$ canopy closure

per storey, open canopy conditions (C), a single-storey stand as described in (A) with wider openings made in 2005 and (D) remnants, single trees with highest growth space and with released crowns that have been growing in open before the start of experiment. All studied stands were situated on the same site and the distance between research plots them did not exceed $800 \mathrm{~m}$. Plot characteristics with spatial and environmental indicators are presented in Table 1.

Competition indicators were derived from the central, predominating tree being as the sample tree and surrounding competitors affecting the crown conditions and the development of the central tree except for the remnants (D). Mensuration parameters of sample tree were presented as the average values for each variant (Table 2 ).

Fructification of the sample trees was monitored from 2008-2011. In 2008 and 2010, none or insignificant amount of crop had been recorded, so no data is presented. Crop abundance in 2009 and 2011 was determined by the use of seed traps (round wire hoops with collection sacks) whose circular trap area was $0.25 \mathrm{~m}^{2}(\mathrm{r}=0.28 \mathrm{~m})$. Traps was placed about $0.5 \mathrm{~m}$ above ground of the soil. For each of the five monitored trees in each stand conditions (A, B, C, D), five seed traps were used in a linear arrangement, in random azimuth direction from the stem foot to its projected crown edge. The direction was chosen with respect to the neighbouring trees (to prevent acorns falling of neighbouring trees). All seed traps were installed on the research plots in September 2009 and August 2011. Acorns were collected at regular intervals of 1-2 weeks. The amount of collected acorns was expressed as the amount of seeds per square $m$ $\left(\mathrm{N}^{\circ} / \mathrm{m}^{2}\right)$ of projected crown with respect to variant.

The "1000 seeds weight" (TSW) was measured and also the germination capacity of acorns harvested in the respective stand situations was tested according to the Czech National Standard (2006) - using $4 \times 50$ seed for all test. Because of the insufficient amount of acorns in treatment (A), the germination capacity could not been evaluated, while for the other stand conditions germination capacity test was established with acorns harvested between 16 Aug.-6 Sept. 2011, 7-20 Sept. 2011, 21 Sept.-4 Oct. 2011 and 5 Oct. -2 Nov. 2011. Damage to the seeds was analysed accordingly with the test of germination capacity. Seeds classified as damaged were acorns affected evidently more than $50 \%$ by insects, fungi or rodents.

To evaluate differences between the individual experimental stand conditions non-parametric Mann\&Whitney and the Kruskall-Wallis tests was applied for the multiple comparisons. Correlations were established by Spearman correlation coefficient using simple linear regression. All statistical analysis was performed with Statistica 10 software.

Table 2. Experimental tree parameters (median and \pm S.E.) and statistical difference for the number of acorns and 1000 seed weight between 2009 and 2011

\begin{tabular}{cccccccccccc}
\hline $\begin{array}{c}\text { Stand } \\
\text { situations }\end{array}$ & $\begin{array}{c}\text { Number } \\
\text { of trees }\end{array}$ & $\mathrm{dbh}[\mathrm{cm}]$ & $\mathrm{A}_{\mathrm{c}}\left[\mathrm{m}^{2}\right]$ & $\mathrm{A}_{\mathrm{soc}}\left[\mathrm{m}^{2}\right]$ & $\mathrm{A}_{\mathrm{rls}}\left[\mathrm{m}^{2}\right]$ & $\begin{array}{c}\text { Acorns }\left(\mathrm{pcs} . \mathrm{m}^{-2}\right) \\
20092011\end{array}$ & p-value & $\begin{array}{c}1000 \text { acorn } \\
\text { weight }-\mathrm{TSW}(\mathrm{g})\end{array}$ & $\mathrm{p}$-value \\
20092011
\end{tabular}

$A$ closed canopy, $B$ slight openness, $C$ wide openness, $D$ remnants, $d b h$ breast height diameter, $\mathrm{A}_{c}$ crown area, $A_{\mathrm{rls}}$ release area (median $\left.\mathrm{d}^{2 *} \varpi\right)$, d distance (sample tree-competitor distance), $\mathrm{A}_{\text {soc }}$ social area (median $\mathrm{d}_{\mathrm{soc}}{ }^{2 *} \varpi, \mathrm{d}_{\mathrm{soc}}=\mathrm{d} \times\left[\mathrm{G}_{\text {central tree }} /\left(\mathrm{G}_{\text {central tree }}+\mathrm{G}_{\text {competitor }}\right)\right]$ ) (Čermák et al. 2006), $p$-value: Mann\&Whitney test at $\alpha=0.05$ 


\section{Results}

The sample trees in same stand conditions had comparable height of the crown setting. The largest at breast height diameter (dbh) was recorded in remnant trees (D), and was significantly different only from the stand conditions (B). Single trees had also the widest crown projection areas, which different only between the categories of dense canopies (A). The largest release area and social area were found under stand conditions $\mathrm{C}$ (significant difference confirmed between A and B). Trees with a larger growth space had larger crown projection areas indicated bigger radial increment (Table 2).
The average number of acorns from analysed stands in 2009 and 2011 was $82 / \mathrm{m}^{2}$ and $66 / \mathrm{m}^{2}$, respectively. The lowest values (number of acorns) were found under fully closed canopy (A). Bigger number of acorns in 2009 and 2011 were recorded under open canopies (C) with $118 / \mathrm{m}^{2}$ and under single trees (D) with $124 / \mathrm{m}^{2}$ (Table 2).

The positive correlation between acorn abundance and canopy openness closely corresponds with the positive correlation between the amount of acorns and release rate individual sample trees (Fig. 2, Table 3). Statistically positive correlations were confirmed between the total crop of seeds and the size of growth space expressed by the social area and by the
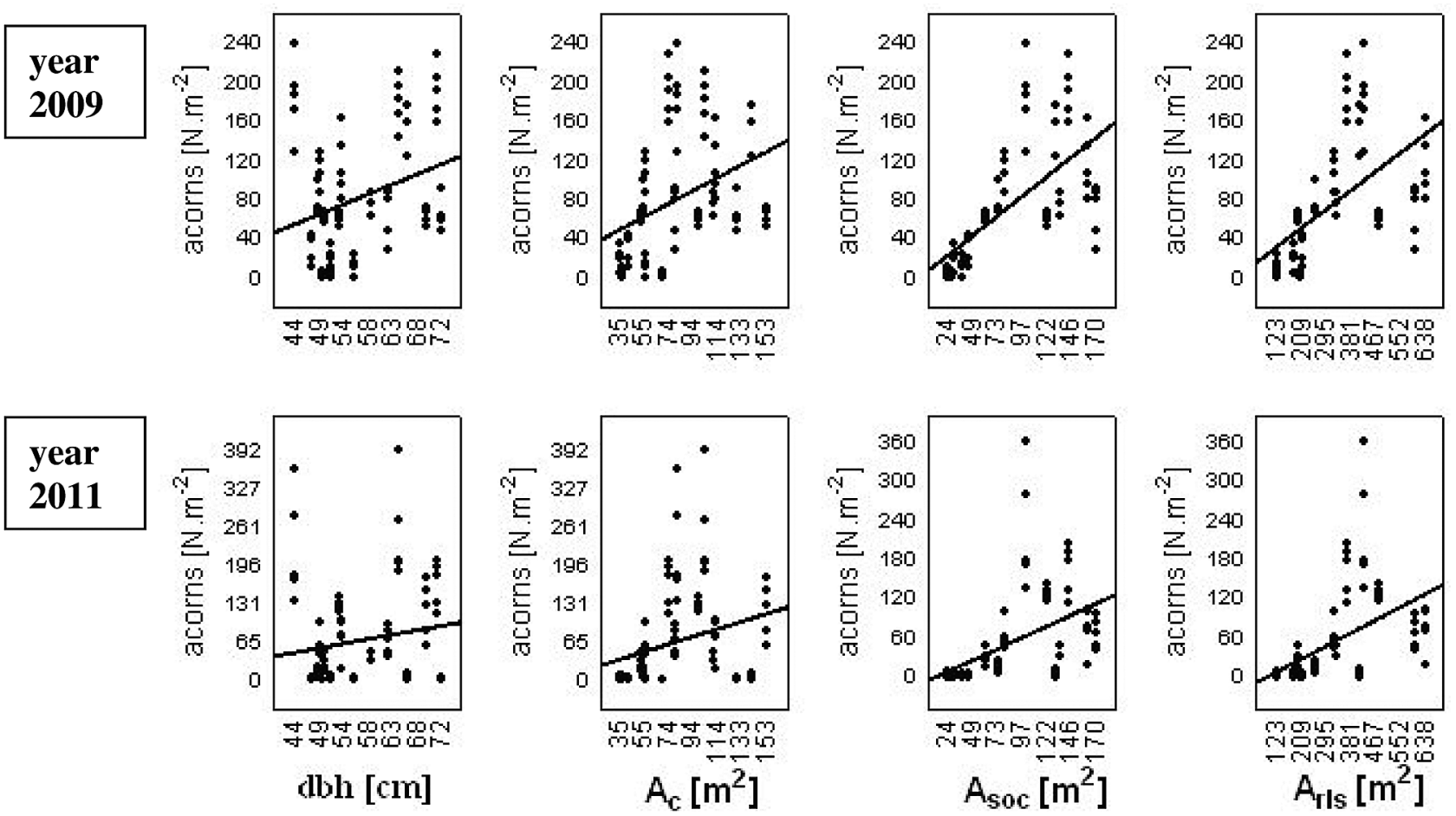

Fig. 1. Regression relations - dependency of the number of acorns (pcs $/ \mathrm{m}^{2}$ ) on diameter at breast height (dbh), crown projection $\left(A_{c}\right)$, social area $\left(A_{\text {soc }}\right)$ and release area $\left(A_{r l s}\right)$ for oaks of all stands conditions in the years 2009 and 2011
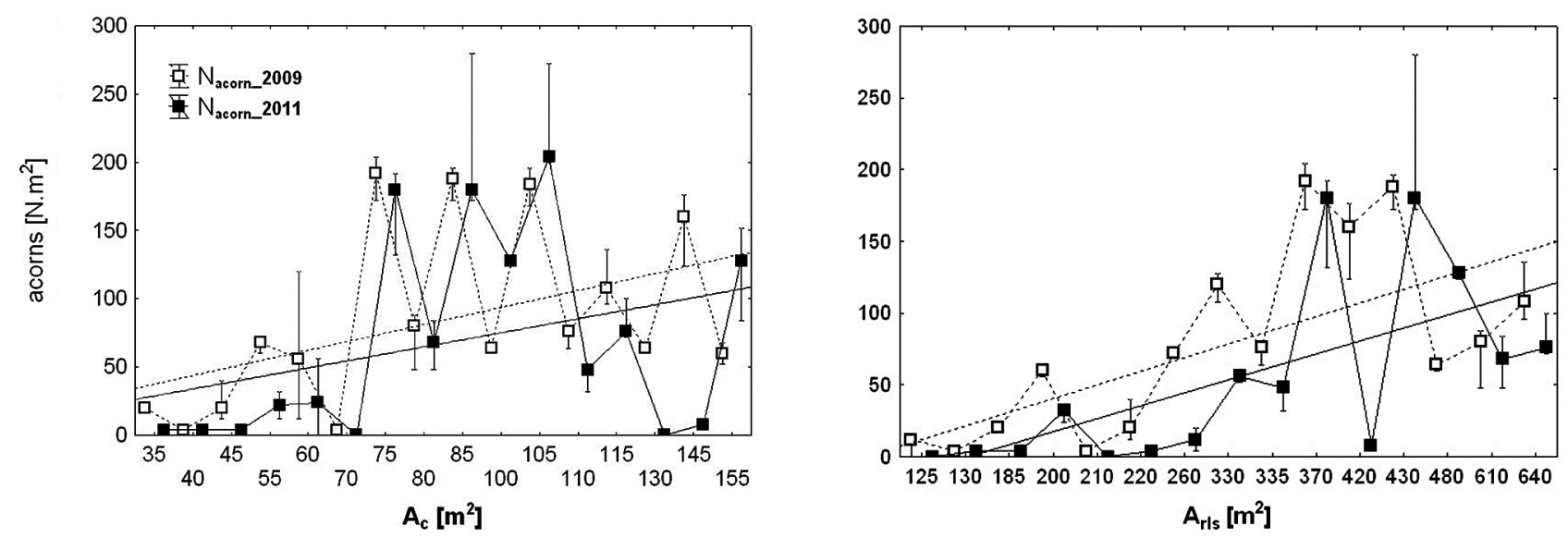

Fig. 2. Number of acorns (pcs $/ \mathrm{m}^{2}$ ) according to the growth parameters (crown projection- $\mathrm{A}_{\mathrm{c}}$, release area- $\mathrm{A}_{\mathrm{rls}}$ ) of sample trees (Quercus robur L.) Zidlochovice (2009 and 2011) 
Table 3. Spearman correlation and regression parameters for the dependency between acorn abundance and the breast height diameter (dbh), crown size (A), social area $\left(\mathrm{A}_{\mathrm{soc}}\right)$ and release area $\left(\mathrm{A}_{\mathrm{rls}}\right)$ for oaks of all stands conditions in 2009 and 2011

\begin{tabular}{lccccc}
\hline & & $\mathrm{dbh}$ & $\mathrm{A}_{\mathrm{c}}$ & $\mathrm{A}_{\text {soc }}$ & $\mathrm{A}_{\mathrm{rls}}$ \\
\hline Acorns & $\alpha$ & -97.28 & -2.81 & 3.33 & 4.83 \\
crop & $\beta$ & 3.24 & 1.10 & 0.82 & 0.22 \\
2009 & $\mathrm{r}_{\text {sprm }}$ & 0.23 & 0.48 & 0.74 & 0.70 \\
& $\mathrm{R}^{2}$ & 0.14 & 0.27 & 0.42 & 0.31 \\
& $\mathrm{p}$-value & $0.001^{* *}$ & $* * *$ & $* * *$ & $* * *$ \\
\hline Acorns & $\alpha$ & 9.80 & 8.9 & -9.43 & -20.63 \\
crops & $\beta$ & 0.84 & 0.63 & 0.71 & 0.23 \\
2011 & $\mathrm{r}_{\text {sprm }}$ & 0.16 & 0.39 & 0.71 & 0.73 \\
& $\mathrm{R}^{2}$ & 0.01 & 0.07 & 0.25 & 0.26 \\
& $\mathrm{p}$-value & 0.470 & $0.023^{*}$ & $* * *$ & $* * *$ \\
\hline
\end{tabular}

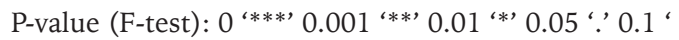

release area or the size of projected crown area below individual trees. Abundant crops (over 50 acorns/ $\mathrm{m}^{2}$ ) were evidenced under trees with the $A_{\text {rls }}$ growth space larger than $300 \mathrm{~m}^{2}$ or with the size of crown projection area and social (territorial) area bigger than $70 \mathrm{~m}^{2}$ (Fig. 1, 2). The least significant studied parameter between different canopy conditions was the number of acorns per dbh.

The repeated crop assessment revealed a varied predisposition of individual trees to fructification. Figure 2 shows that some sample trees fructified in both mast years and surpassed the production of acorns by all other sample trees in the given stand conditions, while others produced either a very low or no crop.

Compared to 2011, 2009 exhibited bigger total number and a higher "1000 seed weight". While the average value in 2009 was 3407 g, in 2011 it was $2329 \mathrm{~g}$. Increasing median values of this parameter with the stand opening (Table 2) are apparent also in the case of "1000 seed weight". The lowest values in both years were recorded under fully closed canopy (A). Statistically significant differences in 1000 seed weight were found only between conditions $\mathrm{A}$ and $\mathrm{C}$ in 2009 (Table 4).
Table 4. Comparison stands conditions in acorns crop parameters between years 2009 and 2011

\begin{tabular}{|c|c|c|c|c|c|c|}
\hline \multirow{2}{*}{$\begin{array}{l}\text { Com- } \\
\text { parison }\end{array}$} & \multicolumn{2}{|c|}{ Acorn crop } & \multicolumn{2}{|c|}{$\begin{array}{c}\text { “1000 seed } \\
\text { weight" (TSW) } \\
\text { of acorns }\end{array}$} & \multicolumn{2}{|c|}{$\begin{array}{c}\text { Acorn crop } \\
2011\end{array}$} \\
\hline & 2009 & 2011 & 2009 & 2011 & $\begin{array}{l}\text { Dam- } \\
\text { age }\end{array}$ & $\begin{array}{l}\text { Capable of } \\
\text { germination }\end{array}$ \\
\hline$A-B$ & + & + & - & - & $\mathrm{N}$ & $\mathrm{N}$ \\
\hline $\mathrm{A}-\mathrm{C}$ & + & + & - & - & $\mathrm{N}$ & $\mathrm{N}$ \\
\hline$A-D$ & + & + & + & - & $\mathrm{N}$ & $\mathrm{N}$ \\
\hline $\mathrm{B}-\mathrm{C}$ & - & - & - & - & - & + \\
\hline B-D & - & - & - & - & - & - \\
\hline C-D & - & - & - & - & + & - \\
\hline
\end{tabular}

A closed canopy, B slight openness, C wide openness, D remnants, $\mathrm{N}$ not analysed, + significant differences, - non significant differences, K-W test $\alpha=0.05$

An assessment of the dynamics of the fall and quality of acorns in 2011 (Fig. 3) indicates that the number of acorns was high and their quality was low at the beginning of the fall. By contrast, at the end of the fall in October, the damage to acorns was low and germination capacity increased from 13 (D) -36 (C) $\%$ to 60 (D) -85 (C) \%.

The differences between the variants in the number of acorns and their damage have also reflected in the total amount of germinable seeds at the end of the fall (Table 4 and 5). In 2011, the highest number of germinable seeds $\left(38 / \mathrm{m}^{2}\right)$ was detected under open canopy conditions. Under solitary trees with the highest number of acorns $\left(124 / \mathrm{m}^{2}\right)$, severe damage resulted in reduced the number of germinable seeds to $30 / \mathrm{m}^{2}$. Under moderate canopy openness with a total number of $75 / \mathrm{m}^{2}$ reached 27 germinable seeds $/ \mathrm{m}^{2}$. Statistically significant differences were found between wide open canopy conditions (C) and remnants (D) in term of percentage of acorn damage and between wide open (C) and slight open canopy conditions (B) in term of acorn germination capacity.

Differences between canopy conditions reflected also in the acorns distribution under the sample trees.
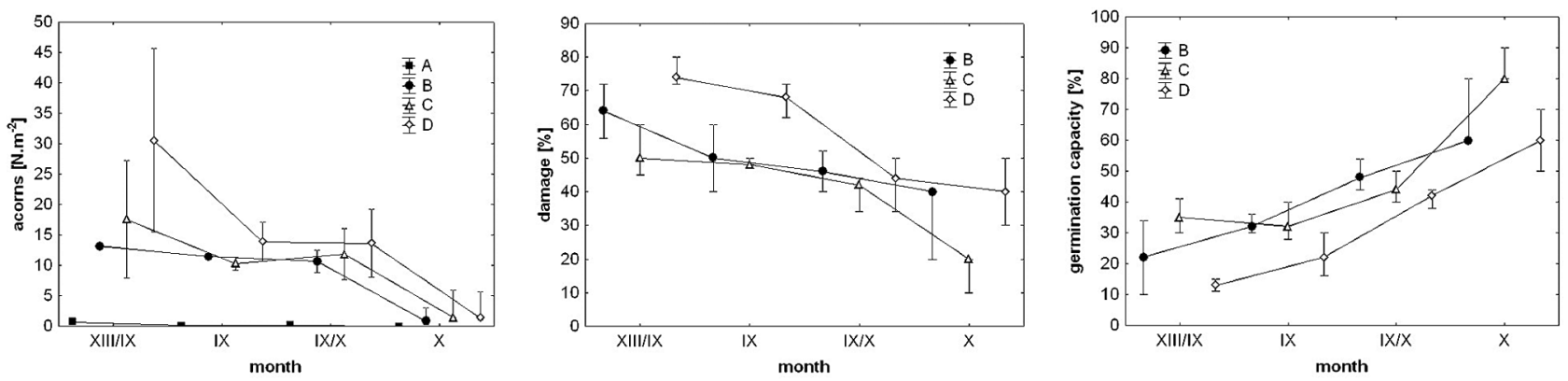

Fig. 3. Acorn fall dynamics $\left(\mathrm{pcs} / \mathrm{m}^{2}\right.$ ), damage (\%) and germination capacity (\%) sampled oak trees in 2011 for different stand conditions (A closed canopy, B slight openness, $\mathrm{C}$ wide openness, D remnants) 
Table 5. Acorn crop characteristics in different stand conditions (2011)

\begin{tabular}{cccc}
\hline & \multicolumn{3}{c}{ Acorn crop 2011 } \\
\cline { 2 - 4 } $\begin{array}{c}\text { Stand } \\
\text { conditions }\end{array}$ & $\begin{array}{c}\text { Total } \\
\left(\text { pcs.m }{ }^{-2}\right)\end{array}$ & $\begin{array}{c}\text { Healthy } \\
\left(\text { pcs.m }{ }^{-2}\right)\end{array}$ & $\begin{array}{c}\text { Capable of } \\
\text { germination } \\
\left.(\text { pcs.m })^{-2}\right)\end{array}$ \\
\hline
\end{tabular}

\begin{tabular}{lrcc} 
A & 2 & $/$ & $/$ \\
B & 75 & 35 & 27 \\
C & 88 & 49 & 38 \\
D & 124 & 45 & 30 \\
\hline
\end{tabular}

A closed canopy, B slight openness, C wide openness, D remnants

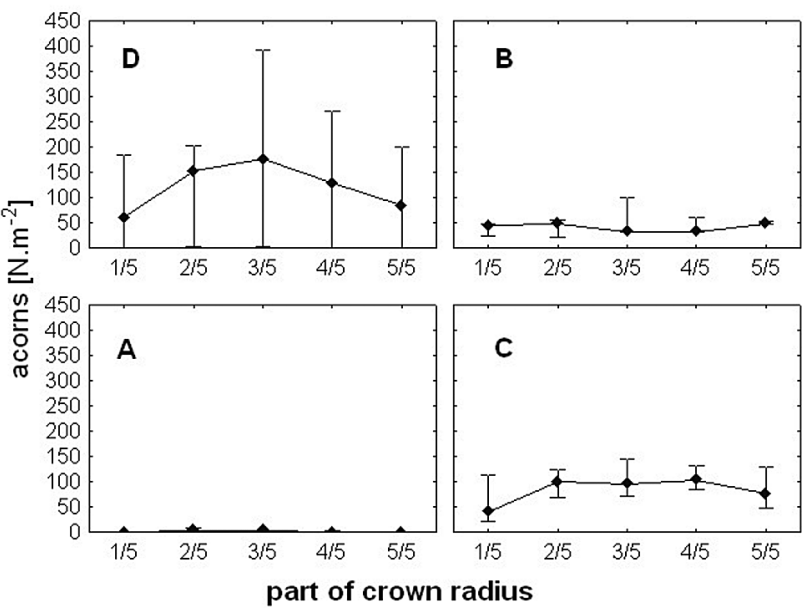

Fig. 4. Number of acorns $\left(\mathrm{No} / \mathrm{m}^{2}\right)$ under sampled trees of different stands conditions (A closed canopy, B slight openness, C wide openness, D remnants) in 2011

While the variants with a higher degree of release (conditions $\mathrm{C}$ and $\mathrm{D}$ ) exhibited the biggest number of acorns under the central part of the crowns, the density of seeds in variant $B$ did not change and was more or less equal (Fig. 4).

\section{Discussion}

A basic prerequisite for successful natural regeneration is a sufficient amount of quality seeds (Vincent 1965; Smith 1986) in to-be-regenerated parent stand. Poor and rare fructification of pedunculate oaks in floodplain forests increase the need for the regeneration by sowing or planting. A commonly used method in practice to increase and stimulate the fructification of forest trees is stand opening with direct purpose to releasing the quality crowns of vital trees in the dominating layer. The opening should start in the early stages of stand development (Matić et al. 1999; Klimo et al. 2008). Apart from the corresponding stand structure, mature stands must have sufficient number of vital individuals with wide, healthy and unobstructed crowns (Dey 1995; Matić et al. 1999).

The beneficial influence of stand openings on the production and quality of acorns has been confirmed by our survey. The production of acorns from the sample trees in the respective stand conditions, which significantly differed from the lowest acorn abundance recorded below fully closed canopy (A). In 2009, the crop from this stand was nine times lower than the crop from the stand in which the canopy area was reduced to $1 / 2(\mathrm{C})$. Compared to the other stand conditions, the 2011 crop from the fully closed canopy (2 acorns per square metre) was negligible.

Studies of red oak (Quercus rubra) from North America are also in accordance with our results. The beneficial influence of stand opening on the production of acorns was reported by Healy et al. (1999), who recorded over an average abundance of acorns in an open red oak stand at $18 / \mathrm{m}^{2}$ a period of eleven years (1986-1996), while in the closed part of the stand was abundance reached only $13.5 / \mathrm{m}^{2}$. At the same time, a crop over $10 / \mathrm{m}^{2}$ was recorded by the authors below the closed canopy conditions three times during the studied period, and six times in the open. By contrast, Bellocq et al. (2005) observed inconclusive differences in the production of red oak acorns on the control plot and on the plot with a 50\% canopy reduction. Nevertheless, the crop was evaluated immediately after the implemented measure when the corresponding response of tree fructification could not yet be expected.

Some older studies on the European beech in which e.g. Markus (1959 in Burschel et al. 1964) recorded a crop of beech nuts that was more abundant at stand margins as compared with conditions below dense stand. Diasporas from trees occurring nearer the stand margin had greater weight and germination capacity. A more abundant crop was detected in stands with a crop density of $0.5-0.6$ as compared with those where crop density was $0.8-0.9$. At that density, the northern faces of tree crowns showed a less abundant crop (41\%), but better quality of the seeds than on the southern faces of the crowns. The beneficial effect of the release of trees on the production of acorns was also apparent in the comparison of individual sample trees with no regard to the stand situation. In our survey, the abundance of the crop of pedunculate oak acorns significantly and closely correlated to the available growth space of the parent tree (see Fig. 2). Our research generally acknowledged empirical knowledge that dominant trees, grown with standards and marginal trees gain more heat and light (Korpel' et al. 1991) and have better dispositions to fructify more frequently and abundantly than trees of lower tree classes and trees inside a dense stand conditions (Vincent 1965). Fruc- 
tification can be positively affected by the long-term continual and consistent support of crown forming through thinning measures and during regeneration felling (Klimo et al. 2008; Matić et al. 1999). The phenomenon is physiologically related to tree nutrition. The number of produced flower primordia is proportional to the amount of supplied assimilates. If the production of assimilates is low, the buds established in the following year are likely to be mainly vegetative. The amount of assimilates needed for reproduction is considerable (ca. $20 \%$ in beech). In this way, tree nutrition and fertility can affect the increment of wood and the frequency of tree flowering (Larcher 1988).

The repeated assessment of fructification demonstrated a considerable variability in the fertility of sample trees in studied stand conditions. Poor fructification of some individuals with desirable growth parameters may be fixed genetically and their finding and removal from the stand should be part of any targeted management of such stands (e.g. Dey 1995; Healy et al. 1999).

\section{Conclusion and recommendations for silvicultural practices}

Pedunculate oak (Quercus robur L.) trees grown in even-aged monocultures on floodplain sites are characterized by poorly developed crowns and small growth space. This consequently results in poor seed production; the suitable solution may be the regeneration with sowing/planting with applied clear-cutting silvicultural system. The timely release at middle ages of targeted pedunculate oak trees which would provide with sufficiently developed crowns (min. ground projection $=$ approximately $70 \mathrm{~m}^{2}$ ) and growth space reaching at least $300 \mathrm{~m}^{2}$ (distance separation of ca. 10 $\mathrm{m})$ could significantly increase crop abundance. The management of mature stands should also include the identification of fructifying oak individuals and their promotion through silvicultural measures.

\section{Acknowledgement}

The paper was written with support from VZ MSM 6215648902 "The Effect of the Coenotic Position of the Parent Tree on the Success of Natural Regeneration in Pedunculate Oak" and was supported by Ministry of Education Youth and Sports of the Czech Republic (Project No. CZ.1.07/2.3.00/20.0267) and the Ministry of Agriculture of the Czech Republic (Project No. QJ1230330).

\section{References}

Askeyev O.V., Tischin D., Sparks T.H., Askeyev I.V. 2005. The effect of climate on the phenology, acorn crop and radial increment of pedunculate oak (Quercus robur) in the middle Volga region, Tatarstan, Russia International Journal of Biometeorology 49: 262-266.

Bellocq M.I., Jones C., Dey D.C., Turgeon J.J. 2005. Does the shelterwood method to regenerate oak forests affect acorn production and predation? Forest Ecology and Management 205: 311-323.

Burschel P., Huss J., Kalbhenn R. 1964. Die natürliche Verjüngung der Buche. J.D. Sauerländer's Verlag, Frankfurt am Main, 186 pp.

Crawley M.J., Long C.R. 1995. Alternate bearing, predator satiation and seedling recruitment in Quercus robur L. Journal of Ecology 83: 683-696.

Czech National Standard (48 1211), 2006. Forest seed management - Collection, quality and test of seed stock quality of forest trees. ČNI, 60 pp.

Čater M., Batič F. 2006. Groundwater and Light Condition as Factors in the Survival of Pedunculate Oak Seedlings. European Journal of Forest Research 125: 419-426.

Čater M. 2011. Osmotic adaptation of Quercus robur L. under water stress in stands with different tree density - relation with groundwater table. Dendrobiology 65: 29-36.

Čermák J., Ulrich R., Staněk Z., Koller J., Aubrecht L. 2006. Electrical measurement of tree root absorbing surfaces by the earth impedance method: 2. Verification based on allometric relationships and root severing experiments. Tree Physiology 26: 1113-1121.

Dey D.C. 1995. Acorn production in red oak. For. Res. Paper No. 127. Ontario Forest Research Institute, Sault Ste. Marie, Canada, 22 pp.

Dey D.C., Spetich M.A., Weigel D.R., Johnson P.S., Graney D.L., Kabrick J.M. 2009. A suggested approach for design of oak (Quercus L.) regeneration research considering regional differences. New Forests 37: 123-135.

Gaertig T., Kirchner H.S., Hildebrand E., Wilpert K. 2002. The impact of soil aeration on oak decline in southwestern Germany. Forest Ecology and Management 159: 15-25.

Gradečki-Poštenjak M., Novak Agbaba S., Licht R., Posarić D. 2011. Dynamics of acorn production and quality of english oak acorn (Quercus robur L.) in disrupted ecological conditions (in Croatian), Šumarski list 135: 169-181.

Healy W.M. 1997. Thinning New England oak stands to enhance acorn production. Northern Journal of Applied Forestry 14: 152-156. 
Healy W.M., Lewis A.M., Boose E.F. 1999. Variation of red oak acorn production. Forest Ecology and Management 116: 1-11.

Harapin M., Halambek M., Liovic B., Novak Agbaba S., Matosevic D., Sever S. 1996. Causes of the absence of acorn crop in Croatia during the period 1991-1995. Zastita suma i pridobivanje drva. Hrvatsko sumarsko drustvo. Skrb za hrvatske sume od 1846 do 1996, knjiga 2: 75-80.

Chalupa V. 1973. Prognosis of acorn crop (in Czech). Práce VÚLHM, Praha, 43: 51-67.

Kelly D. 1994. The evolutionary ecology of mast seeding. Trends in Ecology and Evolution 9: 465-470.

Klimo E., Hager H., Matić S., Anić I., Kulhavý J. 2008. Floodplain Forests of Temperate Zone of Europe, Lesnická práce, Kostelec nad Černými lesy, 623 p.

Koenig W.D., Knops J.M.H., Carmen W.J. 2010. Testing the environmental prediction hypothesis for mast-seeding in California oaks. Canadian Journal of forest Research 40: 2115-2122.

Koenig W.D., Mumme R.L., Carmen W. J., Stenback M.T. 1994. Acorn Production by Oaks in Central Coastal California: Variation within and among Years. Ecology 75: 99-109.

Koenig W.D., Knops J.M.H., Carmen W.J., Stanback M.T., Mumme R.L. 1996. Acorn production by oaks in central coastal California: influence of weather at three levels. Canadian Journal of Forest Research 26: 1677-1683.

Korpel Š., Peňáz J., Saniga M., Tesař V. 1991. Silvculture (in Slovak). Príroda, Bratislava, 465 pp.

Larcher W. 1988. Plants ecophysiology (in Czech) Academia, Praha, 361 pp.

Levanič T., Čater M., McDowell N.G. 2011. Associations between growth, wood anatomy, carbon isotope discrimination and mortality in a Quercus robur forest. Tree Physiology 31: 298-308.

Matić S., Anić I., Oršanić M. 2003. The influence of silvicultural practices on the Sustainability of Forests in Croatia. Ekológia-Bratislava 22: 102-114.

Matić S., Oršanić M., Anić I., Mayer B. 1996. Acorn yields in natural stands of pedunculate oak in Croatia. Unapredenje proizvodnje biomase sumskih ekosustava. Hrvatsko sumarsko drustvo. Skrb za hrvatske sume od 1846. do 1996, knjiga 1: 105111.

Matić S., Oršanić M., Baričević D. 1999. Natural regeneration of pedunculate oak in floodplain forests of Croatia. Ekologia-Bratislava 18: 111-119.

Neuhäuslová Z., Blažková D., Grulich V., Husová M., Chytrý M., Jeník J., Jirásek J., Kolbek J., Kropáč Z., Ložek V., Moravec J., Prach K., Rybníček K., Rybníčková E., Sádlo J. 1998. Map of potential natural vegetation of the Czech Republic. Explanatory text (In Czech). Praha, Academia, 341 p.

Oosterbaan A., Nabuurs G.J. 1991. Relationships between oak decline and groundwater class in The Netherlands. Plant and Soil 136: 87-93.

Palátová E., 2008. Forest establishment I-Forest seed management (in Czech). Skriptum MZLU Brno, $121 \mathrm{pp}$.

Pernar N., Klimo E., Matić S., Bakšić D., Lorencová H. 2009. Different technologies of floodplain forest regeneration from the aspect of soil changes. Journal of Forest Science 55: 357-367.

Poleno Z., Vacek S. 2007. Silviculture II - Theory background of silviculture (in Czech). Lesnická práce, Kostelec nad Černými lesy, 463 pp.

Shaw M.W. 1968. Factors affecting the natural regeneration of sessile oak (Quercus petraea) in north Wales. I. A preliminary study of acorn production viability and losses. Journal of Ecology 56: 565-583.

Smith D.M. 1986. The practice of Silviculture. John Wiley \& sons, Quinn-Woodbine, 527 p.

Svoboda P. 1955. Forest tree species and stands II. SZN, Praha, 573 pp.

Sork V.L., Fleming T.H., Estrada A. 1993. Evolutionary ecology of mast-seeding in temperate and tropical oaks (Quercus spp.). Vegetatio 1993: 133-147.

Vaňková K. 2004. Natural regeneration of oak in floodplain forest (in Czech). Dissertation Mendel university, $164 \mathrm{pp}$.

Vincent G. 1965. Forest seed management (in Czech), SZN, Praha, 329 pp.

Vyskot M. 1958. Oak silviculture (in Czech). ČAZV, Praha, 284 pp. 